It is determined that each of the stages of development of international trade is characterized by certain factors and development trends; features that reflect the level of internationalization of production and the role of international trade in the development of national economies; priority methods of regulating foreign trade by most countries.

The study of the dynamics of world trade since 1800, taking into account its general upward trend, has identified a certain cycle of its development, which at different times was caused by changes in the structure of productive forces, development of new technologies, actions and factors of political and military nature.

The fluctuations obtained as a result of the study have different durations and reach the lowest points of fall and the highest points of growth of world trade at different intervals. The most stable in terms of frequency and amplitude of fluctuations in world trade are the periods from mid-1850 to the First World War and 1950-1974. The most critical is the period 19151938, for which cyclical fluctuations in world exports are characterized by the highest amplitude. Also, statistical analysis of the data allows to determine the cyclical development of the world economy and its synchronicity with the cyclical fluctuations of world trade with the definition of certain cycles equal to 15-18 years.

The current stage is characterized by a slowdown in world export growth. In 2009, the decline in economic activity was the largest among all global recessions. The data show that trade is not even keeping pace with world production growth, and over the past eleven years its average rate has been 2.2\% (with the exception of strong surges in 2010-2011) against $3.07 \%$ of world GDP growth.

The lack of trade dynamism in the last ten years is explained by the weakness of aggregate demand, especially in the euro area. The slowdown in world trade is also linked to the completion of the integration of China and Central and Eastern Europe into the world trading system. The third explanation is the increasing appeal of countries around the world to protectionist measures in international trade in order to stabilize national economies. Many countries have temporarily abandoned normal trade conditions and opted for a more restrained format of mutual trade with other countries.

Determining the prospects for the development of the world economy and international trade, WTO experts provide a range of forecast forecasts for 2020 - from $5 \%$ to $11 \%$ and from $8 \%$ to $20.4 \%$, respectively.

Key words: world trade, cyclicality of world trade, world export, geographical structure of world export.

УДК 378.014 .25

\title{
О.С. Зайковський
}

\section{СУЧАСНІ ЗАКОНОМІРНОСТІ РОЗВИТКУ ІНТЕРНАЦІОНАЛІЗАЦЇ̈ ВИЩОї ОСВІТИ}

\footnotetext{
Анотація. Стаття присвячена дослідженню сучасних трансформацій, що відбуваються у міжнародній мобільності студентів у наслідок поширення прочесів інтернаціоналізації вищої освіти. Обтрунтовано, щуо інтернаціоналізація вищої освіти $\epsilon$ важливою детермінантою розвитку вищої школи, національних економік тощо.

Мета роботи - визначення закономірностей та інтенсивності розвитку інтернаціоналізації у різних країнах та особливостей нащіональних політик щэодо залучення іноземних студентів
} 
Проаналізовано сучасні тенденції у розвитку міжнародної мобільності студентів, виявлено особливості залучення різних країн світу до прочесів академічної мобільності, визначено фактори вибору здобувачів на користь міжнародної освіти. Визначено, що інтернаціоналізачія вищої освіти стала важливою складовою розвитку багатьох країн, які розрізняються за рівнем свого сочіально-економічного розвитку.

Доведено багатоаспектний характер феномену інтернаціоналізації, дослідження якого існує потреба використання багатовимірних оцінок. Запропонований автором методичний інструментарій кількісної оцінки рівня розвитку інтернаціоналізації вищьӧ освіти включає індекс інтернаціоналізації національної системи вищої освіти, використання якого дозволило кількісно оиінити процес інтернаціоналізащії вищьӧ освіти., виявити закономірності розвитку и̧ього процесу у динаміці та їх та інтенсивність.

Обтрунтовано, щуо з макроекономічної точки зору студенти-іноземці виступають важливим фактором впливу на платіжний баланс країни, розвиток національного ринку праці, національної освітньої системи, інновачійного розвитку. Для країнпоходження студенти, які отримали вищу освіту за кордоном, стають важливим джерелом розвитку, за умов повернення таких студентів на батьківщчину. Визначено, щзо сучасні університети активно розвивають стратегі інтернаціоналізації вищої освіти, залучаючи іноземних студентів, які сприяють розвитку рівня міжнародної конкурентоспроможності університетів, забезпечують його фінансову стабільність його розвитку.

Доведено, щзо у відповідь на щорічнозростаючий обсяг кількості іноземних студентів, який спрямованих до високорозвинутих краӥн, національні уряди та університети цих краӥн, будуть спрямовувати свої зусилля на пошук нових шляхів та механізмів залучення на навчання іноземних студентів, у тому числі використовуючи інструменти міграційної політики. Визначено основні напрями та інструменти залучення іноземних студентів.

\section{DOI 10.34079/2226-2822-2020-10-20-70-81}

Дослідження проблематики інтернаціоналізації вищої освіти стали стрімко поширюватись, починаючи з 1980-х років (Knight, 2003). Розвиток інтернаціоналізації як концепції в ретроспективному аспекті, визначення ії моделей та основних тенденцій представлено у роботах Х.де Віта, Ф. Хантер, Л.Ховард (Wit, Hunter, Howard, and EgronPolak, 2015). Сучасні національні політики i програми у частині забезпечення інтернаціоналізації вищої освіти у світі представлено у дослідженні Р.Хелмс, Л.Рамблей та ін. (Helms, Rumbley, Brajkovic, and Mihut, 2015). Слід зазначити, що інтернаціоналізація має різний вплив на характер розвитку національних систем вищої освіти (Е.Егрон-Полак, Р.Хадсон (Egron-Polak and Hudson, 2014), Г. Роадс (Rhoades, 2017).

П.Скотт серед основних аспектів інтернаціоналізації вищої освіти виділяє (Scott, 1998, pp.117-119) розвиток потоків студентів, адміністративного персоналу, розширення співпраці між університетами різних країн, $i$, як наслідок, розвиток потоків не тільки людей, а й ідей. Визначаючи дефініцію інтернаціоналізації в національному, галузевому та інституційному рівні, Дж.Найт, акцентує увагу саме на мету, функції, надання вищої освіти у контексті інтеграційного процесу (у міжнародному, міжкультурному або глобальному вимірі) (Knight, 2003, с.2). Прояви інтернаціоналізації вищої освіти, які притаманні сучасному етапу розвитку освітньої сфери в умовах глобалізації дослідниця (Knight, and Wit, 2018) доповнює наступними: брендинг, міжнародні програми, глобальне громадянство, інтернаціоналізація вдома, масові відкриті онлайн курси, 
глобальні рейтинги, дипломатія знань, університети світового класу, культурна гомогенізація, франчайзинг та спільні програми подвійного ступеня.

Задля виявлення закономірностей розвитку процесу інтернаціоналізації вищої освіти, виникає потреба у дослідженні динамічних змін у міжнародній мобільності студентів, задля визначення закономірностей та інтенсивності розвитку інтернаціоналізації у різних країнах та особливостей національних політик щодо залучення іноземних студентів, що зумовило мету роботи.

Кількість іноземних студентів щороку зростає у світі, про що свідчать показники академічної мобільності. У 1990 році кількість іноземних студентів становила 1,3 млн.осіб, у 2000 році - близько 2 млн., а вже у 2018 році їх кількість сягнула понад 5,57 млн.осіб. До 2025 року за експертними оцінками (із урахуванням подальшого зростання міжнародної студентської мобільності) кількість іноземних студентів складе більше 8 млн. осіб (Wildavsky, 2010).

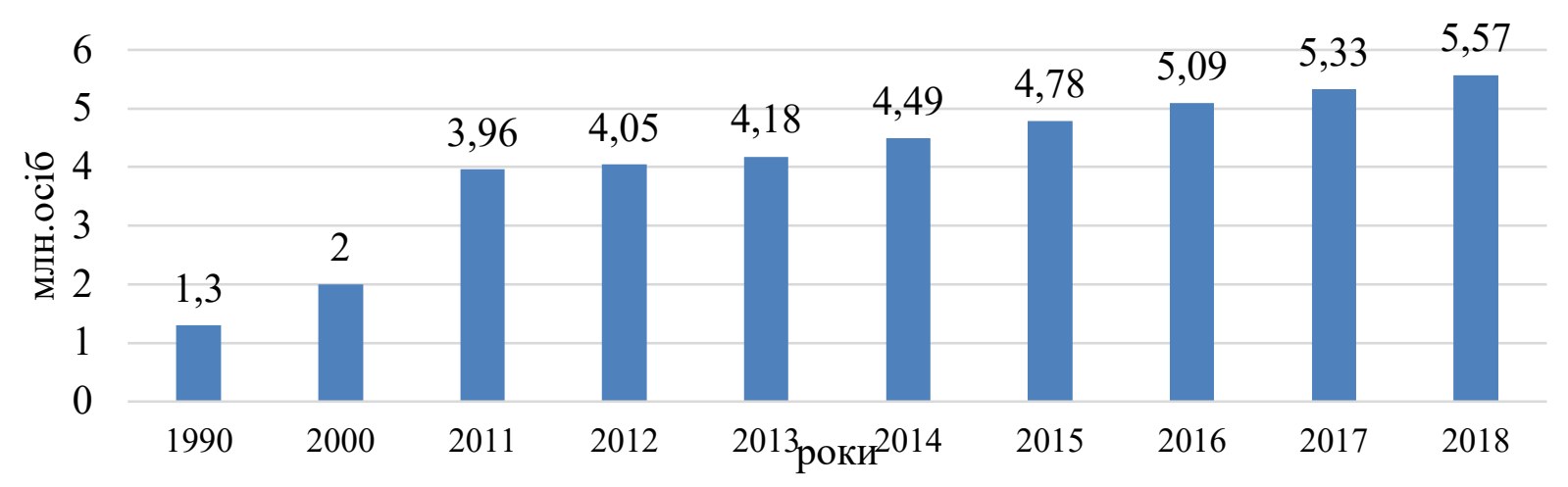

Рис. Динаміка кількості іноземних студентів у світі

Примітка: побудовано за даними (The UNESCO Institute for Statistics (UIS), 2020)

Міжнародна мобільність студентів активно розвивається на користь країн ОЕСР. Основним напрямами потоків студентів, докторантів та дослідників залишаються потоки 3 Азії, які спрямовані до США (найбільші потоки), до Європи тощо (The UNESCO Institute for Statistics (UIS), 2020). Слід зазначити, що зміна чисельності іноземних студентів $\epsilon$ вкрай нерівномірною серед країн, що займають провідні позиції на ринку освітніх послуг, про що наочно свідчать табл.1

Таблиия 1

Зміна чисельності іноземних студентів в основних країнах-лідерах за кількістю студентів-іноземців, \%

\begin{tabular}{|l|r|r|r|r|r|}
\hline Країни & \multicolumn{1}{|c|}{$\mathbf{2 0 1 4}$} & \multicolumn{1}{c|}{$\mathbf{2 0 1 5}$} & \multicolumn{1}{c|}{$\mathbf{2 0 1 6}$} & \multicolumn{1}{c|}{$\mathbf{2 0 1 7}$} & \multicolumn{1}{c|}{$\mathbf{2 0 1 8}$} \\
\hline Австралія & 12372 & 12143 & 12849 & 13558 & 13319 \\
\hline Канада & 47537 & 49919 & 50583 & 49575 & 48345 \\
\hline Китай & 770784 & 819855 & 868319 & 928365 & 993367 \\
\hline Франція & 82073 & 86684 & 90842 & 89412 & 99488 \\
\hline РФ & 55951 & 57438 & 57497 & 56798 & 57632 \\
\hline Великобританія & 30063 & 31479 & 34498 & 36536 & 38986 \\
\hline США & 77963 & 80560 & 83984 & 86596 & 84349 \\
\hline
\end{tabular}

Примітка: побудовано за даними (The UNESCO Institute for Statistics (UIS), 2020). 
Слід підкреслити, що протягом 2014-2018 років питома вага іноземних студентів, що навчаються у зазначених країнах, майже не змінилась і становила близько $24 \%$. Серед європейських країн потоки академічної мобільності з півдня на північ пов'язані із впливом кризи Єврозони. На окрему увагу заслуговує академічна мобільність у напрямі найбільш густонаселених країн світу - Китаю та Індії, що пов'язано із поверненням етнічних діаспор на історичну батьківщину.

У попередніх дослідженнях автора розвинуто методичний інструментарій кількісної оцінки рівня розвитку процесів інтернаціоналізації вищої освіти (Булатова та Зайковський, 2019a; Булатова та Зайковський, 2019b; Bulatova and Zaikovsky, 2020). Обгрунтовано багатоаспектний характер феномену інтернаціоналізації, що об'єктивно обумовлює необхідність застосування багатовимірних оцінок, які базуються на розрахунку комплексних, інтегральних показників розвитку національних систем вищої освіти країн. Запропонований методичний інструментарій кількісної оцінки рівня розвитку інтернаціоналізації вищої освіти включає індекс інтернаціоналізації національної системи вищої освіти, який визначено як багатовимірний показник, що $є$ результатом поєднання системи одиничних параметрів, і який надає комплексну, кількісну характеристику рівня розвитку процесів інтернаціоналізації системи вищої освіти країни на певний момент часу. Запропонований індекс надає можливість кількісно оцінити процеси, які неможливо об'єктивно та системно описати за допомогою окремих одиничних параметрів, поєднує різні аспекти проявів процесу інтернаціоналізації та дозволяє інтерпретувати характер та особливості впливу окремих індикаторів. Задля виявлення закономірностей розвитку процесу інтернаціоналізації вищої освіти, виникає потреба у проведенні розрахунків інтегрального індексу інтернаціоналізації у динаміці, що дозволить виявити закономірності та інтенсивність розвитку цих процесів у країнах.

Грунтуючись на запропонованому методичному інструментарію кількісної оцінки рівня розвитку інтернаціоналізації вищої освіти було розраховано індекси інтернаціоналізації національних систем вищої освіти в динаміці за період 2012-2018 pр. Результати розрахунків наведено в табл.2.

Таблиия 2

Оцінка інтенсивності розвитку процесів інтернаціоналізації країн у 2012-2018 pp.

\begin{tabular}{|l|r|r|r|r|r|r|r|}
\hline & \multicolumn{7}{|c|}{ (ланцюгові темпи зростання індексу), \% } \\
\cline { 2 - 9 } & \multicolumn{1}{|c|}{$2013 /$} & $2014 /$ & $2015 /$ & $2016 /$ & \multicolumn{1}{c|}{$2017 /$} & $2018 /$ & \\
Країна & 2012 & 2013 & 2014 & 2015 & 2016 & 2017 & В середньому \\
\hline Аргентина & $-0,09$ & $-2,52$ & $-1,23$ & $-0,47$ & 1,05 & 0,09 & $-0,53$ \\
\hline Австралія & $-1,21$ & $-3,06$ & 1,11 & 5,87 & 1,57 & $-3,59$ & 0,06 \\
\hline Австрія & 0,59 & $-4,19$ & 0,32 & $-0,51$ & $-0,32$ & 2,52 & $-0,28$ \\
\hline Бельгія & $-0,08$ & 4,91 & 3,26 & 2,67 & $-14,59$ & $-4,83$ & $-1,68$ \\
\hline Бразилія & 9,79 & 8,08 & 11,72 & 3,39 & 2,59 & $-0,57$ & 5,74 \\
\hline Болгарія & $-3,26$ & 1,66 & $-1,72$ & $-1,34$ & $-2,91$ & $-0,24$ & $-1,32$ \\
\hline Канада & $-4,00$ & 4,05 & 2,70 & 0,02 & $-0,22$ & $-4,11$ & $-0,31$ \\
\hline Чилі & 4,39 & $-0,36$ & 2,86 & 0,29 & 0,65 & $-1,56$ & 1,03 \\
\hline Китай & 5,99 & $-4,05$ & 3,05 & 11,79 & $-0,71$ & 2,71 & 3,01 \\
\hline Хорватія & $-2,53$ & 2,21 & 2,28 & 3,25 & $-1,56$ & 2,78 & 1,05 \\
\hline Чехія & $-4,70$ & 2,25 & 0,92 & 0,96 & 1,21 & 2,78 & 0,54 \\
\hline Данія & 1,56 & $-4,21$ & 3,81 & 3,12 & $-2,67$ & $-4,95$ & $-0,62$ \\
\hline Фінляндія & 1,96 & 2,20 & 2,98 & 1,05 & $-0,84$ & $-5,63$ & 0,24 \\
\hline
\end{tabular}


ISSN 2518-1394 (Online), ISSN 2226-2822 (Print) ВІСНИК МАРІУПОЛЬСЬКОГО ДЕРЖАВНОГО УНРСИТЕТУ СЕРІЯ: ЕКОНОМІКА, 2020, ВИП 20

\begin{tabular}{|l|r|r|r|r|r|r|r|}
\hline \hline Франція & $-1,34$ & $-0,71$ & 0,90 & $-2,35$ & $-0,86$ & $-3,22$ & $-1,27$ \\
\hline Німеччина & $-0,88$ & 0,38 & 0,05 & $-2,04$ & 0,52 & $-4,00$ & $-1,01$ \\
\hline Греція & $-2,38$ & 0,33 & $-2,92$ & $-2,17$ & 1,86 & $-2,34$ & $-1,29$ \\
\hline Угорщина & 3,86 & 3,30 & $-2,64$ & 6,67 & 3,37 & $-1,83$ & 2,07 \\
\hline Індія & 36,07 & 3,70 & $-6,21$ & $-5,33$ & $-6,53$ & $-12,35$ & 0,43 \\
\hline Ірландія & $-3,37$ & $-2,00$ & $-26,38$ & 39,35 & 0,77 & 0,83 & $-0,22$ \\
\hline Ізраїль & 2,03 & $-10,04$ & 2,76 & 2,35 & $-12,22$ & 1,61 & $-2,46$ \\
\hline Італія & $-0,18$ & 5,81 & $-2,17$ & $-1,11$ & $-2,58$ & $-2,39$ & $-0,48$ \\
\hline Японія & 0,94 & $-0,41$ & 4,23 & 3,22 & $-7,29$ & $-5,76$ & $-0,94$ \\
\hline Корея & $-2,13$ & $-4,16$ & 1,07 & $-1,31$ & 1,11 & $-3,82$ & $-1,56$ \\
\hline Малайзія & 4,58 & 1,19 & $-2,13$ & $-4,96$ & $-6,14$ & $-3,65$ & $-1,92$ \\
\hline Мексика & 0,16 & 3,71 & 0,18 & $-6,24$ & 4,35 & $-0,94$ & 0,14 \\
\hline Нідерланди & 4,36 & 1,34 & 2,22 & 2,00 & 2,60 & $-5,30$ & 1,15 \\
\hline Нова Зеландія & $-1,71$ & 0,50 & $-1,74$ & 0,84 & $-0,77$ & $-1,18$ & $-0,68$ \\
\hline Норвегія & $-5,40$ & $-0,48$ & 0,45 & 2,95 & $-6,06$ & $-5,81$ & $-2,46$ \\
\hline Польща & 4,72 & 8,05 & 3,59 & 0,47 & 3,27 & $-1,41$ & 3,07 \\
\hline Португалія & $-2,14$ & 0,66 & 5,52 & 8,16 & 2,72 & $-2,33$ & 2,03 \\
\hline Румунія & 3,33 & 11,39 & $-1,32$ & 7,00 & $-5,09$ & 2,91 & 2,90 \\
\hline Росія & $-6,68$ & $-7,68$ & 5,90 & $-8,69$ & $-7,51$ & $-17,22$ & $-7,22$ \\
\hline Сербія & $-0,11$ & 7,17 & 3,30 & $-3,90$ & 0,02 & 2,22 & 1,39 \\
\hline Сінгапур & 16,78 & 1,37 & $-0,16$ & 19,94 & $-3,20$ & 2,92 & 5,92 \\
\hline Словаччина & $-2,91$ & 4,08 & 10,22 & $-8,30$ & $-0,87$ & 3,26 & 0,74 \\
\hline Словенія & 2,47 & 1,48 & 3,34 & 5,72 & $-1,69$ & 4,08 & 2,54 \\
\hline Іспанія & $-0,55$ & 3,56 & 3,14 & $-1,33$ & 1,93 & $-3,49$ & 0,51 \\
\hline Швеція & $-0,13$ & $-0,07$ & 1,20 & 2,29 & $-1,80$ & $-3,83$ & $-0,41$ \\
\hline Швейцарія & $-2,12$ & 0,25 & $-1,74$ & 0,15 & 0,22 & $-6,86$ & $-1,71$ \\
\hline Таїланд & $-0,66$ & 1,37 & 2,29 & $-0,23$ & $-2,47$ & $-3,41$ & $-0,54$ \\
\hline Туреччина & $-2,85$ & 4,83 & $-0,92$ & 4,67 & 1,14 & $-2,69$ & 0,65 \\
\hline Україна & $-0,64$ & 3,42 & 8,87 & 1,14 & $-13,66$ & 0,28 & $-0,34$ \\
\hline Великобританія & 1,36 & 0,30 & $-0,33$ & 0,65 & $-1,10$ & $-3,75$ & $-0,49$ \\
\hline США & 0,83 & $-0,76$ & 6,00 & 4,03 & $-10,20$ & $-7,03$ & $-1,36$ \\
\hline
\end{tabular}

Примітка: розрахунки автора

Як показують результати оцінки інтенсивності динаміки процесів інтернаціоналізації за інтегральним рівнем, до країн з найбільш інтенсивними темпами розвитку процесів інтернаціоналізації системи вищої освіти слід віднести Сінгапур (зростання індексу на 5,92\% в середньому щорічно за період 2012-2018 pp., 3 максимальним збільшенням у 2016 р. - 19,94), Бразилію $(5,74 \%$ щорічно в середньому 3 максимальним приростом у 2015 р. - 11,72\%), Польщу (3,07\% щорічно в середньому 3 максимальним приростом у 2014 р. - 8,05\% з наступним уповільненням зростання), Китай (3,01\% щорічно в середньому з максимальним приростом у 2016 р. - 11,79\%). До країн, що також характеризуються в середньому зростаючими темпами інтернаціоналізації, належать Австралія, Чилі, Хорватія, Чехія, Фінляндія, Угорщина, Індія, Мексика, Нідерланди, Португалія, Румунія, Сербія, Словенія та Іспанія. Решта досліджуваних країн мають від'ємні темпи розвитку процесів інтернаціоналізації, при цьому слід відзначити несуттєвий (до $2 \%$ в середньому щорічного скорочення у 2012- 
2018 рр.) рівень скорочення. Серед таких країн найбільше середньорічне скорочення індексу інтернаціоналізації мають Росія (-7,22\%), Ізраїль та Норвегія (по -2,46\%). Досліджуючи загальну тенденцію зміни індексів, встановлено для всіх країн вибірки відсутність загального тренду зміни інтегрального рівня інтернаціоналізації, зокрема коливання періодів збільшення та збільшення інтегрального рівня, що свідчить про різновекторність процесів та їх достатньо мінливий характер.

Інтернаціоналізація вищої освіти стала важливою складовою розвитку багатьох країн, які розрізняються за рівнем свого соціально-економічного розвитку. Практично за усіма прогнозними оцінками різноманітних міжнародних інституцій, дослідницьких груп, агенцій тощо кількість іноземних студентів буде щороку зростати, більшість яких буде обирати для отримання вищої освіти розвинуті країни. Відповідно, університети, національні уряди країн будуть спрямовувати свої зусилля на пошук нових шляхів та механізмів залучення на навчання іноземних студентів, у тому числі використовуючи інструменти міграційної політики.

Збільшення кількості бажаючих отримати вищої освіти, у першу чергу, в країнах із низьким та середнім рівнем доходу, відповідно, посилюють попит, при цьому кількість університетів у країнах із високим рівнем доходу суттєво не змінюється. Відповідно, університети цих країн стають більш залежними саме від кількості студентів 3 менш розвинутих країн. Слід підкреслити, що вартість вищої освіти зростає значно вищими темпами, випереджаючи інфляцію цін на споживчі товари, медичні витрати, продовольчі товари тощо. Так за даними агентства Bloomberg, в США вартість навчання у середньому за останні 40 років зросла в 12 разів, тоді як витрати на медичні послуги зросли на $601 \%$, а ціни на продукти харчування зросли на $244 \%$ за той же період (Jamrisko, and Kolet, 2012). Відповідно, зростаюча вартість робіть університети менш доступними, що вимагає додаткових зусиль з боку закладів вищої освіти щодо розвитку пропозицій більш якісних програм, які роблять більш конкурентоспроможними випускників університетів на ринку.

Значна кількість країн світу (Канада, Німеччина, Японія, Китай та інші) активно підтримують не тільки залучення іноземних студентів до своїх університетів, а й зорієнтовують сою політику на те, що б залишити висококваліфіковану робочу силу на своєму ринку.

Так, поширення англомовних магістерських програм в Німеччині до 1032 проти 198 англомовних бакалаврських програм (Nafie, 2017) дозволило збільшити кількість іноземних студентів на 12\% (що становить майже третину від усіх студентів-магістрів). Половина іноземних студентів, які здобувають освіту в Німеччині, вирішають залишитися, а близько 40\% планують залишитися принаймні 10 років (Marsh, 2017).

Уряд Канади (Hemmadi, 2016) запровадив нову стратегію (Global Skills Strategy), метою якої є залучення іноземних висококваліфікованих фахівців у високотехнологічні сектори економіки, що забезпечують високий рівень зростання. У цьому урядовому документів окремо визначено механізм залучення до національної економіки іноземців, що отримали освіту в університетах Канади, шляхом спрощення отримання віз, дозволів на працевлаштування. Як наслідок, половина іноземних студентів, які здобувають освіту в Канаді, планують подати заяву на постійне проживання після отримання вищої освіти в Канаді.

Активну політику щодо залучення іноземних студентів 3 подальшим працевлаштуванням на національному ринку поступово впроваджує Китай, пропонуючи спрощений механізм отримання посвідки на проживання, урядові стипендії, різноманітні програми, що дозволяють отримати дозвіл на працевлаштування для випускників місцевих університетів (Sharma, 2017), послабив правила проживання для іноземців, що працюють у інженерних науково-дослідних центрах, технологічних 
центрах високотехнологічних компаній, що акредитовані державою, зарубіжних науково-дослідних центрах тощо. Слід зазначити, що у 2017 році в Китаї навчалось близько 0,489 млн. іноземних студентів. Кількість китайських студентів, що навчаються за кордоном, є вищою, і становить понад 0,608 млн. студентів. Кількість іноземних аспірантів та докторантів, що навчаються та проводять дослідження в китайських університетах становить 75800 осіб, що на 18,6\% більше попереднього року (для порівняння, зростання інших категорій іноземних студентів становить 15\%) (Sharma, 2018). Якщо раніше основні зусилля китайського уряду було спрямовано на повернення безпосередньо китайських громадян, що отримали освіту за кордоном, на історичну батьківщину, то у теперішній час відбувається зміщення акцентів у напрямок залучення іноземців, які сприятимуть розвитку китайських інновацій, що зменшить рівень залежності від промислового експорту та розширить високотехнологічний експорт та електронну комерцію китайських компаній.

Аналогічні зусилля щодо залучення іноземних студентів активно впроваджує японський уряд, пропонуючи цільові освітні програми, програми з працевлаштування, що включають субсидії для стажування в японських компаніях, додаткові мовні курси, спрощений візовий механізм тощо.

3 іншого боку, дії урядів можуть призвести до негативного пливу на розвиток міжнародної мобільності студентів. Так, а експертними оцінками міжнародної компанії Hobsons (Redden, 2016), яка провела опитування серед студентів британських університетів напередодні референдуму щодо Brexit, 35\% іноземних студентів, які приїхали на навчання до університетів Великобританії не з країн $€ C$, та 82\% студентів 3 країн ЄС визначили менш привабливим навчання в університетам Великобританії у разі виходу країни з ЄС. Кількість студентів 3 країн Євросоюзу, що навчаються в університетах Великобританії, яка стабільно щороку зростала, після оголошення Brexit почала скорочуватись. Якщо у 2016-2017 навчальному році зростання кількості студентів становило 7\%, то у 2018-2019 навчальному році їх чисельність скоротилась на $3 \%$, у тому числі в аспірантуру на 9\% (Jack, 2019). Можна передбачити, що ситуація буде тільки ускладнюватись, оскільки Великобританія не зможе отримувати після виходу з СС дослідницькі гранти за програмою «Horizon 2020», Свропейської ради досліджень, приймати участь у програмі Erasmus + на попередніх умовах. Окрім невизначеності щодо студентів 3 країн СС наявні антиміграційні настрої у процесі реалізації Brexit також не сприяють залученню на навчання в британські університети іноземних студентів з інших країн світу, які, скоріш за все, будуть переорієнтовувати свій вступ до університетів Канади, Австралії, країн $Є С$ тощо, де умови навчання більш визначені і не має антиміграційних настроїв.

Обмежувальна міграційна політика, що реалізує адміністрація Д.Трампа, суттєво вплинула на закордонний попит на вищу освіту в США та зниження кількісних результатів міжнародної мобільності нових студентів. Так, незважаючи на те, що загальна кількість іноземних студентів, що здобувають освіту в американських університетах залишається найвищою у світі, кількість нових міжнародних студентів у 2018 році становила близько 272 тис.осіб, що на 6,6\% менше у порівняні із попереднім роком і на $10 \%$ менше у порівнянні із 2015-2016 навчальним роком, коли до американських університетів вступила найбільша кількість іноземних студентів (Open Doors, 2018). Серед факторів, що стримують мобільність іноземних студентів, найбільш негативний вплив забезпечують саме візові процедури (затримка, обмеженні тощо), які пов'язані із змінами у зовнішній політиці, що реалізує адміністрація Д.Трампа. Суттєвий вплив формують соціальне та політичне середовище в США, вартість навчання тощо. 
Загальна тенденція лібералізації міжнародних економічних відносин - вільного обігу капіталу, товарів, послуг - посилює попит на міжнародні процеси обміну освітою, наукою, інноваціями. Ринки стають більш глобалізованими, а від так, освіта, що отримана за кордоном, сприяє наближенню до цих ринків. Посилення взаємозалежності та взаємопов'язаності країн світу вимагає від робочої сили відповідних навичок, які все більше стають важливими у глобальному контексті.

Залучення іноземних студентів все більше привертає увагу урядів, безпосередньо університетів. 3 макроекономічної точки зору студенти-іноземці виступають важливим фактором впливу на платіжний баланс країни через валютні надходження, внутрішньокраїнові споживання тощо), Крім того вони стають важливим джерелом розвитку національного ринку праці (за рахунок залучення талановитих випускників 3 числа студентів-іноземці, що опанували програми вищої школи та залишились у країні, де вони здобули вищу освіту), національної освітньої системи (шляхом залучення талановитої молоді, академічного персоналу тощо), інноваційного розвитку тощо.

Для країн-походження студенти, які отримали вищу освіту за кордоном, стають важливим джерелом розвитку, за умов повернення таких студентів на батьківщину. І тут мова йде не тільки про нові можливості високотехнологічного розвитку, які отримує країна, що повертає висококваліфікованих фахівців із якісною міжнародною освітою, оскільки останні сприяють розвитку міждержавних відносин, інтегруванню національної системи у глобальні мережі. Університети також активно розвивають стратегі інтернаціоналізації вищої освіти, залучаючи іноземних студентів, які сприяють розвитку рівня міжнародної конкурентоспроможності університетів, забезпечують його фінансову стабільність його розвитку, оскільки іноземні студенти зазвичай сплачують більш високу ціна за навчання порівняно із національними студентами.

Вибір на користь міжнародної освіти, для майбутніх здобувачів вищої освіти зумовлено наступними факторами. По-перше, в багатьох країнах існують певні обмеження щодо здобуття вищої освіти на відповідних рівнях за відповідними освітніми програмами. 3 одного боку, таке навчання обирають більш заможні студенти, чиї родини спроможні оплатити навчання за кордоном, а 3 іншого, уряди деяких країн використовують відповідні програми підтримки навчання за певними спеціальностями та спеціалізаціями. Провідні університети світу, які реалізують дослідницькі проекти світового ринку, стають більш привабливими для іноземних студентів/докторантів, які розглядають своє навчання в таких університетах, як відповідне інвестування, що у майбутньому матиме більшу прибутковість.

\section{Бібліографічний список}

Булатова, О.В. та Зайковський, О.С., 2019а. Глобалізація освітнього простору: основні характеристики та принципи розвитку. Вісник Маріупольського державного університету. Серія: Економіка, 17, с.63-71. DOI: 10.34079/2226-2822-2019-9-1763-71

Булатова, О.В. та Зайковський, О.С., 2019b. Оцінка рівня розвитку процесів інтернаціоналізації національних систем вищої освіти на основі використання багатовимірних показників. Науковий вісник Ужгородського начіонального університету. Серія: Міжнародні економічні відносини та світове господарство, 28(1), c.69-75. DOI: https://doi.org/10.32782/2413-9971/2019-28-12

Bulatova, O. and Zaikovsky, O., 2020. International mobility of students in modern conditions of transformation in the global market of services (regional aspect). Research Papers in Economics and Finance, 4(2), pp.19-27. https://doi.org/10.18559/ref.2020.2.2 
Chentukov, Y.I. and Marena, T., 2020. Higher Education Internationalization as a Factor of Improving University Competitiveness. Вісник Маріупольського державного університету. Серія: Економіка, 19, pp.104-112. DOI: 10.34079/2226-2822-2020-1019-104-112

Egron-Polak, E. and Hudson, R., 2014. Internationalization of Higher Education: Growing expectations, fundamental values: IAU 4th Global Survey. Paris: International Association of Universities.

Helms, R.M., Rumbley, L.E., Brajkovic, L. and Mihut, G., 2015. Internationalizing Higher Education Worldwide: National Policies and Programs. Washington: American Council on Education. DOI: 10.13140/RG.2.2.12513.51044

Hemmadi, M., 2016. Canada has overhauled its immigration process for international students. Canadian Business, [online] November 11. Available at: $<$ https://www.canadianbusiness.com/economy/canada-has-overhauled-its-immigrationprocess-for-international-students/> (Accessed 20 November 2020).

Jack, A., 2019. EU student enrolment drops at top UK universities. Financial times, [online] 4 January. Available at: <https:/www.ft.com/content/32072762-0f6b-11e9-a3aa$118 \mathrm{c} 761 \mathrm{~d} 2745>$ (Accessed 20 November 2020).

Jamrisko, M. and Kolet, I., 2012. Cost of College Degree in U.S. Soars 12 Fold: Chart of the Day. Bloomberg, [online] August $15 . \quad$ Available at: $<$ https://www.bloomberg.com/news/articles/2012-08-15/cost-of-college-degree-in-u-ssoars-12-fold-chart-of-the-day> (Accessed 20 November 2020).

Kalil, T. and Jahanian, F., 2013. Computer Science is for Everyone! The White House President Barack Obama, [online] December 11. Available at: $<$ https://obamawhitehouse.archives.gov/blog/2013/12/11/computer-scienceeveryone $>$ (Accessed 20 November 2020).

Kharas, H., 2017. The Unprecedented Expansion Of The Global Middle Class An Update. Global Economy \& Development WorkingPaper100. [online] Available at: $<$ https://www.brookings.edu/wp-content/uploads/2017/02/global_20170228_globalmiddle-class.pdf $>$ (Accessed 20 November 2020).

Knight, J. and Wit, H., 2018. Internationalization of Higher Education: Past and Future. International Higher Education, 95, pp.2-4. DOI: https://doi.org/10.6017/ihe.2018.95.10715

Knight, J., 2003. Updating the Definition of Internationalization. International Higher Education, 33, pp.2-3. DOI: https://doi.org/10.6017/ihe.2003.33.7391

Marsh, N., 2017. Int'l students in Germany up 6\% as English-taught masters gain. The PIE News, [online] April 6. Available at: $<$ https://thepienews.com/news/intl-students-ingermany-up-6-as-english-taught-masters-gain-popularity/> (Accessed 20 November 2020).

Nafie, R., 2017. What Germany is doing right to edge past the competition. The PIE News, [online] Apr 7. Available at: <https://thepienews.com/analysis/germany-edge-pastcompetition-international-students/> (Accessed 20 November 2020).

Open Doors, 2018. Institute of International Education. [online] Available at: $<$ https://www.iie.org/Research-and-Insights/Open-Doors> (Accessed 20 November 2020).

Redden, E., 2016. Brexit's Enrollment Effects. Inside Higher ED, [online] June 29. Available at: <https://www.insidehighered.com/news/2016/06/29/british-universities-brace-likelydrop-eu-students $>$ (Accessed 20 November 2020).

Rhoades, G., 2017. Backlash Against "Others". International Higher Education, 89, pp.2-3. DOI: https://doi.org/10.6017/ihe.2017.89.9830 


\section{ISSN 2518-1394 (Online), ISSN 2226-2822 (Print) ВІСНИК МАРІУПОЛЬСЬКОГО ДЕРЖАВНОГО УНРСИТЕТУ СЕРІЯ: ЕКОНОМІКА, 2020, ВИП 20}

Scott, P., 1998. Massification, Internationalization and Globalisation. In: P. Scott, Ed., 1998. The Globalization of Higher Education. Buckingham: SRHE and Open University Press, pp.108-129.

Sharma, Y., 2017. Talent drive looks to bring in international students. University World News, [online] 17 March. Available at: $<$ http://www.universityworldnews.com/article.php?story=20170316161911243> (Accessed 20 November 2020).

Sharma, Y., 2018. International student numbers near half a million. University World News, [online] 03 May. Available at: $<$ https://www.universityworldnews.com/post.php?story=20180503165205109> (Accessed 20 November 2020).

The UNESCO Institute for Statistics (UIS), 2020. [online] Available at: $<$ http://uis.unesco.org/ $>$ (Accessed 20 November 2020).

Wildavsky, B., 2010. The Great Brain Race: How Global Universities Are Reshaping the World. Princeton: Princeton University Press.

Wit, de H., Hunter, F., Howard, L. and Egron-Polak, E., 2015. Internationalisation of higher education. [online] Available at: <https://www.europarl.europa.eu/RegData/etudes/STUD/2015/54 0370/IPOL_STU(2015)540370_EN.pdf> (Accessed 20 November 2020).

\section{References}

Bulatova, O. and Zaikovsky, O., 2019a. Hlobalizatsiia osvitnoho prostoru: osnovni kharakterystyky ta pryntsypy rozvytku [Globalization of educational space: main characteristics and principles of development]. Visnik Mariupol's'kogo deržavnogo unìversitetu. Seriâ. Ekonomika, 17, pp.63-71. DOI: 10.34079/2226-2822-2019-9-17-6371 (in Ukrainian).

Bulatova, O. and Zaikovsky, O., 2019b. Otsinka rivnia rozvytku protsesiv internatsionalizatsii natsionalnykh system vyshchoi osvity na osnovi vykorystannia bahatovymirnykh pokazn [Estimation of development level of the national higher education system internationalization processes on the basis of multidimensional indicators]. Uzhorod National University Herald. International Economic Relations And World Economy, 28(1), pp.69-75. DOI: https://doi.org/10.32782/2413-9971/2019-28-12 (in Ukrainian).

Bulatova, O. and Zaikovsky, O., 2020. International mobility of students in modern conditions of transformation in the global market of services (regional aspect). Research Papers in Economics and Finance, 4(2), pp.19-27. https://doi.org/10.18559/ref.2020.2.2

Chentukov, Y.I. and Marena, T., 2020. Higher Education Internationalization as a Factor of Improving University Competitiveness. Visnik Mariupol's'kogo deržavnogo universitetu. Seriâ : Ekonomika, 19, pp.104-112. DOI: 10.34079/2226-2822-2020-10-19-104-112

Egron-Polak, E. and Hudson, R., 2014. Internationalization of Higher Education: Growing expectations, fundamental values: IAU 4th Global Survey. Paris: International Association of Universities.

Helms, R.M., Rumbley, L.E., Brajkovic, L. and Mihut, G., 2015. Internationalizing Higher Education Worldwide: National Policies and Programs. Washington: American Council on Education. DOI: 10.13140/RG.2.2.12513.51044

Hemmadi, M., 2016. Canada has overhauled its immigration process for international students. Canadian Business, [online] November 11. Available at: $<$ https://www.canadianbusiness.com/economy/canada-has-overhauled-its-immigrationprocess-for-international-students/> (Accessed 20 November 2020). 
Jack, A., 2019. EU student enrolment drops at top UK universities. Financial times, [online] 4 January. Available at: <https:/www.ft.com/content/32072762-0f6b-11e9-a3aa$118 \mathrm{c} 761 \mathrm{~d} 2745>$ (Accessed 20 November 2020).

Jamrisko, M. and Kolet, I., 2012. Cost of College Degree in U.S. Soars 12 Fold: Chart of the Day. Bloomberg, [online] August 15. Available at: $<$ https://www.bloomberg.com/news/articles/2012-08-15/cost-of-college-degree-in-u-ssoars-12-fold-chart-of-the-day> (Accessed 20 November 2020).

Kalil, T. and Jahanian, F., 2013. Computer Science is for Everyone! The White House President Barack Obama, [online] December 11. Available at: <https://obamawhitehouse.archives.gov/blog/2013/12/11/computer-scienceeveryone $>$ (Accessed 20 November 2020).

Kharas, H., 2017. The Unprecedented Expansion Of The Global Middle Class An Update. Global Economy \& Development WorkingPaper100. [online] Available at: $<$ https://www.brookings.edu/wp-content/uploads/2017/02/global_20170228_globalmiddle-class.pdf $>$ (Accessed 20 November 2020).

Knight, J. and Wit, H., 2018. Internationalization of Higher Education: Past and Future. International Higher Education, 95, pp.2-4. DOI: https://doi.org/10.6017/ihe.2018.95.10715

Knight, J., 2003. Updating the Definition of Internationalization. International Higher Education, 33, pp.2-3. DOI: https://doi.org/10.6017/ihe.2003.33.7391

Marsh, N., 2017. Int'l students in Germany up 6\% as English-taught masters gain. The PIE News, [online] April 6. Available at: $<$ https://thepienews.com/news/intl-students-ingermany-up-6-as-english-taught-masters-gain-popularity/> (Accessed 20 November 2020).

Nafie, R., 2017. What Germany is doing right to edge past the competition. The PIE News, [online] Apr 7. Available at: <https://thepienews.com/analysis/germany-edge-pastcompetition-international-students/> (Accessed 20 November 2020).

Open Doors, 2018. Institute of International Education. . [online] Available at: $<$ https://www.iie.org/Research-and-Insights/Open-Doors $>$ (Accessed 20 November 2020).

Redden, E., 2016. Brexit's Enrollment Effects. Inside Higher ED, [online] June 29. Available at: <https://www.insidehighered.com/news/2016/06/29/british-universities-brace-likelydrop-eu-students $>$ (Accessed 20 November 2020).

Rhoades, G., 2017. Backlash Against "Others". International Higher Education, 89, pp.2-3. DOI: https://doi.org/10.6017/ihe.2017.89.9830

Scott, P., 1998. Massification, Internationalization and Globalisation. In: P. Scott, ed. 1998. The Globalization of Higher Education. Buckingham: SRHE and Open University Press, pp.108-129.

Sharma, Y., 2017. Talent drive looks to bring in international students. University World News, [online] 17 March. Available at: $<$ http://www.universityworldnews.com/article.php?story=20170316161911243>

(Accessed 20 November 2020).

Sharma, Y., 2018. International student numbers near half a million. University World News, [online] 03 May. Available at: $<$ https://www.universityworldnews.com/post.php?story=20180503165205109> (Accessed 20 November 2020).

The UNESCO Institute for Statistics (UIS), 2020. [online] Available at: < http://uis.unesco.org/> (Accessed 20 November 2020).

Wildavsky, B., 2010. The Great Brain Race: How Global Universities Are Reshaping the World. Princeton: Princeton University Press. 
Wit, de H., Hunter, F., Howard, L. and Egron-Polak, E., 2015. Internationalisation of higher education.

[online] Available at: $<$ https://www.europarl.europa.eu/RegData/etudes/STUD/2015/54 0370/IPOL_STU(2015)540370_EN.pdf $>$ (Accessed 20 November 2020).

Стаття надійшла до редакції $\overline{15.08 .2020 .}$

\section{O. Zaikovsky}

\section{MODERN PATTERNS OF DEVELOPMENT HIGHER EDUCATION INTERNATIONALIZATION}

Summary. The article is devoted to the study of modern transformations taking place in the international mobility of students due to the spread of higher education internationalization.

It is substantiated that the internationalization of higher education is an important determinant of higher education development, national economies, and the like.

The objective of the work is to determine the regularities and intensity of the development of internationalization in different countries and the features of the national policy on attracting foreign students.

It is determined that higher education internationalization has become an important component of the development of many countries that differ in their level of socioeconomic development. The author of article analyzes the current trends in the development of international student mobility, identifies the features of attracting different countries to the processes of academic mobility, and determines the factors of choosing applicants in favor of international education.

The multidimensional nature of the phenomenon of internationalization is proved, in the study of which there is a need to use multidimensional estimates. The proposed methodological tools by author for the quantitative assessment of the level of development of internationalization of higher education includes an index of national higher education system internationalization, the use of which allowed to quantify the process of internationalization of higher education., To identify patterns of development of this process in dynamics, and their intensity.

It is substantiated that from the macroeconomic point of view, foreign students are an important factor in influencing the country's balance of payments, the development of the national labor market, the national educational system, and innovative development. Students who have received higher education abroad become an important source of development for the countries of origin, on the terms of the return of such students to their motherland. It is determined that modern universities develop strategies for internationalization of higher education actively, attracting foreign students, which contribute to the development of the level of international universities competitiveness, providing its financial stability of its development.

It is proved that in response to the annual growth in the number of foreign students who are sent to highly developed countries, national governments and universities of these countries will direct their efforts to find new ways and arrangements to attract foreign students to study, including using the tools of migration policy. The main directions and methods of attracting foreign students are defined. 